CHAPTER TWENTY-ONE

\title{
DEMOSTHENES
}

\section{M.J. EdWARDS}

By no means all narratives in forensic speeches are recounted in one single unit. The complex inheritance cases that form the corpus of extant speeches by Isaeus, for example, tend to have two, three or more narrative sections, which help (at least on the face of it) to make the details more intelligible to the jurors. ${ }^{1}$ Another good example of a narrative being split into several parts (in this case three) is provided by Demosthenes in his speech 55, Against Callicles. ${ }^{2}$ Here, the unnamed son of Teisias defends himself against a prosecution for damages brought against him by Callicles. The two men own adjacent farms in a hilly farm district, divided by a public road, and Callicles sues the speaker for water damage to his farm caused by a wall along the road, built by the speaker's father, that had dammed a watercourse.

\section{Order}

The first narrative part $(\$ \S 3-4)$ recounts the main event of this speech, the building of the wall by the speaker's father. The main point the narrator wants to make is that this event took place long ago (more than fifteen years, 'almost before I was born', while both their fathers were still alive) and that neither at the moment of building was a protest raised nor during this long period of time was any complaint made, 'and yet of course it rained then, just as it does now'. The detail that at the time of the building Callicles was already an adult and living in Athens carries the double implication that he is unfairly using his greater experience against the speaker, part of the picture the speaker

\footnotetext{
${ }^{1}$ Cf. M.J. Edwards 2006: 76-78.

${ }^{2}$ For discussions of this speech see Blass i887-1898: III.r 253-257; Usher 1999: I86I89.
} 
paints of him as a sycophant, and again that, being in Athens, unlike his father, Callicles did not know exactly what was going on on the farm. Earlier the narrator had already remarked, much in the same vein, that the father 'of course knew the facts more accurately than these men [Callicles and his brother Callicrates, who is also present in court]'. The narrative ends here and is followed by a section of proofs, in which the speaker elaborates on the central point of the preceding narrative, asking his opponent why no complaint had been made earlier and suggesting that the reason for his present conduct is malicious prosecution ('sycophancy'), a charge made right at the start of the speech and reiterated on numerous occasions ( $\$ \S$ I, 2, 6, 9, 2I, 22, $23,26,28,29,33,35){ }^{3}$

The second narrative part follows in $\S \S 9-$ II. As announced in the argumentation just preceding, the narrator now wants to explain, through his narrative, that his father 'committed no wrong in walling in the land'. In order to do so, he starts by saying that the land around which the wall was built was private property, a fact admitted by the opponents. He then briefly turns to the recent past, just prior to the trial (no exact time-marker), and recounts his failed attempt at arbitration by local people who know the situation. This then naturally leads into a description, in the present tense, of the properties of the two parties and the road that divides them. The narrator explains that the two sides' properties were separated by a road, and since their farms were surrounded by hills, rainwater would flow partly down the road and partly onto the farms. The relevance of this description becomes immediately clear in the sequel, when the narrator goes back into the past for a second time, now to a time before that recounted in the first narrative part, viz. when the piece of land 'was inundated after a heavy downpour' (no time-marker), an event which induced his father to build the wall. But before he tells this, he first goes back in time even more, to the time (no time-marker) when the property belonged to another, unnamed man, who neglected it. During his ownership the water overflowed on two or three occasions, damaging the land and starting to make a channel for itself. The narrator then returns to the time of the father, who sees the damage caused by the latest inundation, as well as

3 This was, of course, a commonplace accusation made by defendants against their prosecutors, but the speaker here is unusually persistent in his claim, perhaps because he had lost earlier cases. 
encroachments of his neighbours, and builds the wall (§ I2). Temporally, therefore, we are now back to the moment when the first narrative part opens in $\S 3$.

We see that the building of the wall, recounted in the first narrative part as a fact from the past, is now looked at again from a legal point of view: the speaker's father had the right to build the wall, since it was his property, it was no watercourse, and he was suffering from real damage through inundation. The narrator is careful to indicate how he knows about his father's motives (after all he was still very young when the building took place), by adding his source: 'so I am informed by those acquainted by the circumstances'. This remark must also compensate for the circumstance that the case is tried not by locals, as he had wanted, but by a court in Athens. For this same reason the narrator engages his audience, the jurors: 'if you could have seen the place, you would know at once that I am the victim of sycophancy'. ${ }^{4}$

As in the case of the first narrative part, the second narrative part carefully lays the foundation for the argumentation that follows, where the speaker mainly addresses the point that the piece of land is not a watercourse but private land. The argument repeats parts of the narrative (the land is private property) and occasionally adds new details (the land has trees and tombs on it, and hence cannot be a watercourse).

After this set of proofs, the narrator comes to his third narrative part $\left(\S \S 23^{-24}\right)$, the purpose of which, as again is announced in the argumentation preceding it, is to demonstrate that the damage Callicles' property had suffered was very minor, thereby indicating once more that he was acting maliciously in asking for a fine of a thousand drachmae. The narrator now goes back to a point of time (no specific timemarker) after the alleged damage to Callicles' land, but prior to the suit (significantly referred to as 'this malicious action against me').

The speaker's mother, as he explains in an introductory section, was a long-standing friend of the mother of the opponents, just as their husbands had been (a new detail; in $\S 3$ we had only heard that the men were neighbours). When she visited Callicles' mother, the latter told her in tears what had happened. The narrator is careful to add it was through his mother, herself an eyewitness (twice stressed, §24), that

\footnotetext{
${ }^{4}$ Note the striking verb sukophantoumai (§9).
} 
he himself got to know about what had happened, a source likely to be taken as reliable by the jury, and a fact which the speaker buttresses with a prayer for blessings if he is telling the truth and the opposite if he is lying. This prayer is presumably added by the narrator because, as we noted with the mother in Lysias' $(\rightarrow$ ) Against Diogeiton, he could not bring his mother into court as a witness. Unlike Lysias, Demosthenes does not attempt to give the woman direct speech, but this was perhaps unnecessary: even in indirect speech her report suffices to make clear that the actual damage was minor. The point of her report is made explicit by the narrator at the start of the argumentation which follows on his last narrative: 'So trivial, men of the jury, was the loss that befell them, yet for this I am made defendant in a suit with damages fixed at a thousand drachmae!' This then leads to another instance of the speaker's repeated charge that Callicles is acting like a sycophant, and the remaining proofs seek to drive this message home to the jurors, with occasional repetition of parts of the earlier narrative (e.g. 'But since in the beginning my father was within his rights in enclosing the land and these people never made any complaints during the lapse of so long a time ...', $\left.\S_{26}\right)$.

On the basis of the three narrative parts we can reconstruct the fabula of Demosthenes' Against Callicles as follows: (A) neglect by an earlier owner, (B) leads to inundations, (C) which induces the new owner to build a wall. (D) After more than fifteen years this wall during a heavy rainfall allegedly damages the property of the plaintiff. (E) The narrator's mother visits the neighbour's farm and hears about the damage, (F) which she reports to her son. $(\mathrm{G}) \mathrm{He}$ attempts to settle the matter by local arbitration, but this attempt fails and a lawsuit follows. We see that this fabula is turned into a story with a different order of events: (first narrative part) $\mathrm{C}$ - (second narrative part) $\mathrm{G}-\mathrm{B}-\mathrm{A}-\mathrm{C}-$ (third narrative part) $\mathrm{E}-\mathrm{F}$. As this overview shows, the alleged fact of the damaging of the plaintiff's property $(\mathrm{D})$ is never recounted by the speaker (who presumably was not present at the farm) and only the results are reported to him by his mother.

\section{Speed and frequency}

The first part of the narrative is told singulatively and in summary style. This speed is suggestive of the main point the speaker is making: that fifteen years passed without any incident (indeed, as the third part will 
make clear, with the two neighbours and their wives living happily next to each other). The central point itself, that no complaints were lodged, is made at length, with a succession of clauses (out' ... oute ... oud' ... all' oud' ... oude ...) and five different verbs expressing forms of protestation.

The second part of the narrative again starts in summary style, when the speaker refers to his call for private arbitrators. Then follows a narrative pause, in which the narrator gives a detailed description of the road between the two properties and how these are surrounded by a mountain from which water runs down, partly into the road, partly onto the farms. The water that pours into the road flows down the road when there is no obstruction, but necessarily overflows onto the farms when there is one. The balanced detail is striking, and continues. The actual inundation which led his father to build the wall is told very briefly, but when recounting the handling of the land by its previous owner the narrator turns to iterative narration, to stress that there had been 'two or more' earlier inundations. Likewise, the second reason for the father to build the wall is told in iterative narration: 'neighbours started to encroach upon the property and walk across it'.

The third stage of the narrative starts off with an introduction of the two mothers in iterative and summary style: 'they were intimate friends' and 'they used to visit each other', to which a summary detail about the fathers is added ('their husbands had been friends while they lived'). The pace slows down, appropriately, when the narrator comes to the vital point of his mother being told about and later seeing with her own eyes and finally reporting to her son the damage. Her report is given in indirect speech, with the details of the damage to the barley, wheat and jar of olive oil being carefully recorded, culminating in the jar not being damaged at all. The repeated and emphatic negation (ou ... ouden) forms a fitting climactic - or better bathetic - end to the third part of the narrative.

\section{Other examples}

Demosthenes, of course, was more than capable of composing extended blocks of narrative in the manner of Lysias $(\rightarrow)$. A fine example of his technique in this regard is the narrative of speech 54, Against Conon. The main story is told in four stages, separated by witness statements, and as is regular practice in the orators, some more details appear later in 
the speech, inserted into the argumentation. ${ }^{5}$ But one of the marks of Demosthenes' supreme talent was the ability to adapt his speeches to the rhetorical requirements of the situation. The Against Callicles is an example of this. On a far larger scale, in his masterpiece On the Crown, Demosthenes narrates the history of his career in three chronological stages, the crucial third stage (the alliance with Thebes prior to the defeat at Chaeronea) being subdivided into two parts: his career down to $346 \mathrm{BC}(\S \S 17-52)$, his career from $34^{6-340 \mathrm{BC}}\left(\S \S 53^{-109}\right)$, the Theban alliance ( $\$ \mathrm{I}^{\mathrm{I}} 6 \mathrm{O}-\mathrm{I} 79$ and $\left.2 \mathrm{II}-226\right)$. In the middle of the second and third stages he sandwiches his defence against the technical charges for which Aeschines was prosecuting Citesiphon, perhaps because his arguments on these points are his weakest. ${ }^{6}$ In between the two parts of the Theban narrative he inserts a comparison between himself and Aeschines ( $\left.\S \mathrm{I}_{\mathrm{I}} 8 \mathrm{O}-\mathrm{I} \mathrm{I} \mathrm{I}\right)$, and a justification of his policy $(\$ \S \mathrm{I} 92-2 \mathrm{IO})$ : the former is prepared for by an attack on Aeschines' parentage and career in $\S \S$ I22-I59; the latter, with the claim 'do not put the blame on me if Philip happened to prevail in the battle: its outcome was in the hands of the gods, not mine' (§ I93), which prepares for the uncomfortable telling of the securing of the doomed alliance with Thebes.

\section{Conclusion}

The speech by Demosthenes analysed in this chapter shows that though there is a tendency in the Attic orators to narrate the story in chronological order, whether in one or several parts, an anachronical order is found too. Dividing the narrative into three parts, the narrator moves through time both forward and backward, choosing an order which is most effective. Like Antiphon $(\rightarrow)$ and Lysias $(\rightarrow)$ Demosthenes effectively varies the speed of his narration to accentuate or downplay parts of his story.

\footnotetext{
${ }^{5}$ For an analysis see $S A G \mathcal{N}$ 1:344-346.

6 The so-called ordo Homericus. Cf. Usher 1993: I7-I9.
} 